\title{
POLITYKA WZGLĘDEM ODNAWIALNYCH ŹRÓDEL ENERGII W POLSCE I JAPONII - ANALIZA PORÓWNAWCZA
}

\author{
POLICY TOWARDS RENEWABLE ENERGY SOURCES IN POLAND \\ AND JAPAN - COMPARATIVE ANALYSIS
}

\begin{abstract}
In the era of globalization and increasing consumer awareness about caring for the environment, an important factor is the implementation of environmentally friendly and sustainable installations, in order to reduce the negative impact of human activity on the environment. The turning point of this concern for "clean planet" is the use of renewable energy sources and increase their share of total electricity consumption. The aim of this article is a comparative analysis of conditions for the development of renewable energy in Poland and Japan.
\end{abstract}

Keywords: renewable energy sources, policy, Poland, Japan

JEL classification: O13, P18, Q48

\section{Wstęp}

Polski bilans surowców energetycznych powinien stymulować wdrażanie odnawialnych źródeł energii (OZE), bowiem szacowany jest na 28,67 Gtoe, z których jedynie 10,09 Gtoe jest zagospodarowane. Poprzez oparcie produkcji energii elektrycznej na węglu kamiennym polska gospodarka w znacznym stopniu naraża się na ryzyko niedostatecznej podaży energii i niepewność związaną z płynnością dostaw surowców importowanych oraz niestabilnością cen ${ }^{1}$. Polska po przystąpieniu do Unii Europejskiej 1 maja 2004 roku dobrowolnie wyraziła zgodę na przestrzeganie polityki UE, a także dostosowanie własnych programów do standardów panujących we Wspólnocie. Ratyfikując pakiet klimatyczno-energetyczny,

* Josai International University 城西国際大学.

${ }^{1}$ L. Gawlik, E. Mokrzycki, A. Uliasz-Bocheńczyk, Potencjat odnawialnych źródel energii w Polsce, [w:] J. Tarajkowski (red.), Czynnik ENERGIA w polityce gospodarczej, Wydawnictwo Poznańskie Towarzystwo Przyjaciół Nauk, Poznań 2010, s. 13. 
zobowiązała się do osiągnięcia do 2020 roku, w porównaniu z rokiem bazowym, celów znanych jako „3×20”, a więc:

- zmniejszenia o $20 \%$ emisji gazów cieplarnianych,

- zwiększenia o 20\% efektywności energetycznej,

- zwiększenia o 20\% udziału OZE w całkowitym zużyciu energii elektrycznej.

Niezwykle istotną rolę w wypełnieniu tych zadań mogą odegrać odnawialne źródła energii, dzięki którym możliwe jest ograniczenie emisji gazów cieplarnianych (poprzez mniejsze użycie konwencjonalnych paliw), a także dzięki rozproszeniu - zwiększenie efektywności energetycznej, przy jednoczesnym zmniejszeniu wykorzystywania energii pierwotnej.

Z kolei Japonia na początku XXI wieku uchodziła za kraj, który posiada jeden z najbardziej zaawansowanych i nowoczesnych technicznie sektorów energetycznych na świecie. Do 2011 roku często poruszano kwestie niemalże doskonałego, „wyregulowanego”, a także konkurencyjnego japońskiego systemu zarządzania sektorem energetycznym. Katastrofa z Fukushimy (2011 rok) uzmysłowiła, jak te opinie dalekie były od rzeczywistości, a korporacyjny model zarządzania „staroświecki”. Spowodowała także ograniczenia w produkcji energii jądrowej i wzrost zainteresowania energetyką odnawialną. Tragiczne wydarzenia $z$ dnia 11 marca 2011 roku wywołały jedną z najdroższych katastrof naturalnych na świecie. Przyczyniło się to do znacznej zmiany poglądów na temat energetyki jądrowej i wzrostu zainteresowania odnawialnymi źródłami energii. Raport Nicolasa Newmana opublikowany w marcu 2012 roku w PennWell (Power Engineering International) poruszył problem konieczności wybrania jak najlepszego z punktu widzenia ekonomiczno-socjologiczno-ekologicznego modelu krajowej polityki energetycznej ${ }^{2}$. Artykuł rozpatruje kwestie, czy Japonia gotowa jest na zmiany w strukturach energetyki, a także jak daleko można się w tych zmianach posunąć. Za sprawą ogromnego braku akceptacji opinii publicznej dla aktualnej polityki energetycznej (nasilonego po wydarzeniach z marca 2011 roku), prowadzonej przez kilka kluczowych przedsiębiorstw, japoński rząd został zmuszony do zaproponowania „odświeżenia” japońskiego systemu energetycznego ${ }^{3}$. W ramach zmian zastosował stopniowe wyłączanie reaktorów atomowych zapoczątkowane w 2011 roku, by 5 maja 2012 roku dokonać całkowitej ich redukcji. Był to nie lada cios dla japońskiego sektora energetycznego, gdyż w 2010 roku udział produkcji energii z atomu wynosił $26 \%$ produkcji ogółem ${ }^{4}$. Wyłączenie reaktorów atomowych zmusiło rząd japoński do zwiększenia importu surowców naturalnych potrzebnych do produkcji energii elektrycznej oraz spojrzenia na sektor

${ }^{2}$ www.PowerEngineeringint.com (dostęp: 10.07.2016).

3 Według sondażu przeprowadzonego przez Wall Street w 2012 roku $51 \%$ badanych sprzeciwia się ponownemu włączeniu elektrowni atomowych, $40 \%$ badanych obywateli jest jednak za energią jądrową.

${ }^{4}$ A. Rajewski, Japonia bez atomu - co najmniej do grudnia, http://adamrajewski.natemat. pl/75005,japonia-ponownie-bez-atomu (dostęp: 10.07.2016). 
energetyczny pod kątem zwiększenia udziału odnawialnych źródeł energii w bilansie energetycznym kraju.

W niniejszym artykule przeprowadzona zostanie analiza porównawcza uwarunkowań funkcjonowania sektorów energetycznych w Polsce i Japonii pod kątem szans rozwoju sektora OZE.

\section{Odnawialne źródła energii w polskim systemie energetycznym}

Polska, aby zapewnić bezpieczeństwo energetyczne kraju i w pełni zrealizować postawione przed nią założenia pakietu klimatyczno-energetycznego, wdrożyła następujące dokumenty strategiczne:

- Politykę Energetyczną Polski do 2030 roku,

- Krajowy Plan Działania w zakresie energii ze źródeł odnawialnych,

- Kierunki Rozwoju Biogazowni Rolniczych w Polsce na lata 2010-2020.

Rada Ministrów dnia 10 listopada 2009 roku wprowadziła dokument Polityka Energetyczna Polski do 2030 roku, która określa prognozę polskiego zapotrzebowania na energię, strategię rozwoju sektora energetycznego, a także kierunki działań dla rozwoju energetyki. Głównymi kwestiami poruszonymi w tym dokumencie są zmniejszenie negatywnego wpływu sektora energetycznego na środowisko, a zarazem zwiększenie efektywności energetycznej oraz udziału odnawialnych źródeł energii. Wspomniany postęp efektywności energetycznej ma zachodzić poprzez realizację następujących celów:

- zeroenergetyczny wzrost gospodarczy;

- zbliżenie energochłonności polskiej gospodarki do średniej europejskiej (w Polsce jest nadal około dwukrotnie wyższa energochłonność PKB w porównaniu do U-15);

- wsparcie dla technologii wysokosprawnej kogeneracji i wzrost sprawności produkcji energii elektrycznej;

- wzrost końcowej efektywności wykorzystania energii,

- ograniczenie strat związanych z przesyłem i dystrybucją energii elektrycznej ${ }^{5}$.

Wskutek wdrożenia ustawy o efektywności energetycznej powstał program wsparcia tzw. białych certyfikatów ${ }^{6}$. Ponadto poprzez wspieranie badań i stosowanie bodźców rozwojowych dla wysokosprawnej kogeneracji, a także wspomaganie inwestycji sprzyjających ograniczeniu zużycia energii, polski rząd chce zrealizować cel zawarty w dyrektywie 2006/32/WE, zobowiązujący Polskę do zwiększenia

${ }^{5}$ Polityka Energetyczna Polski do 2030 roku, Uchwała Rady Ministrów nr 202/2009 z dnia 10 listopada $2009 \mathrm{r}$.

${ }^{6}$ Białe certyfikaty służą celom oszczędnościowym energii elektrycznej. Są to tzw. świadectwa efektywności energetycznej pobudzające racjonalne wykorzystanie energii elektrycznej. 
oszczędności energii rzędu 53452 GWh do 2016 roku (stanowi to 9\% średniego zużycia energii elektrycznej w latach 2001-2005) ${ }^{7}$.

W ramach rozwoju odnawialnych źródeł energii zawartych w Polityce Energetycznej Polski do 2030 roku głównymi celami do osiągnięcia są:

- piętnastoprocentowy udział OZE w całościowym zużyciu energii do 2020 roku i dwudziestoprocentowy ich udział w 2030 roku,

- dziesięcioprocentowy udział biopaliw w rynku paliw transportowych w 2020 roku,

- powszechniejsze stosowanie biopaliw II generacji ${ }^{8}$,

- wykorzystanie terenów rolniczych do lokowania OZE,

- wykorzystywanie urządzeń piętrzących będących własnością Skarbu Państwa do produkcji energii elektrycznej,

- ochrona lasów przed nadmiernym ich eksploatowaniem?.

Realizacja wyżej wymienionych celów ma się odbywać poprzez szereg działań, m.in.:

- planowanie i organizację działań zgodnych z ideą zrównoważonego rozwoju dzięki:

- Krajowemu Planowi Działań,

- możliwości nadawania inwestycjom w OZE statusu celu publicznego,

- zmianę regulacji prawnych związaną ze zwiększaniem udziału biokomponentów w paliwach transportowych,

- utrzymanie mechanizmów wsparcia dla producentów energii elektrycznej ze źródeł odnawialnych,

- wprowadzenie nowej metody obliczania realizacji Narodowego Celu Wskaźnikowego ${ }^{10}$,

- podwyższenie w paliwach ciekłych udziału biokomponentów,

- stosowanie ulg i zwolnień podatkowych dla biopaliw,

- wsparcie pozyskiwania z odpadów biodegradowalnych „czystej energii” poprzez rozwój technologii oraz montaż instalacji,

- utworzenie przyjaznych warunków inwestycyjnych dla budowy farm wiatrowych na morzu,

- wdrożenie kierunków budowy biogazowni rolniczych,

- dalsze podtrzymywanie zasady zwalniającej pochodzącą z odnawialnych źródeł energii akcyzę,

${ }^{7}$ Krajowy Plan Działania w zakresie energii ze źródeł odnawialnych, Ministerstwo Gospodarki, Rada Ministrów z dnia 10 grudnia 2010 r.

${ }^{8}$ Biopaliwa II generacji są to biopaliwa wytworzone z materiałów niekonkurujących z żywnością (np. słoma).

9 Polityka Energetyczna Polski do 2030 roku, Uchwała Rady Ministrów nr 202/2009 z dnia 10 listopada $2009 \mathrm{r}$.

${ }^{10}$ Narodowy Cel Wskaźnikowy stosowany jest w transporcie i określa minimalny odsetek paliw odnawialnych i biokomponentów w ogólnej ilości paliw użytych w danym roku kalendarzowym. 
- pobudzanie i dynamizacja potencjału przemysłu produkującego urządzenia dla OZE,

- wsparcie dla budowy nowych ośrodków OZE oraz sieci elektroenergetycznych ze środków funduszy ochrony środowiska i funduszy europejskich,

- wprowadzenie instrumentów wsparcia dla większego wytwarzania ciepła i chłodu z odnawialnych źródeł energii ${ }^{11}$.

Uchwalony 7 grudnia 2010 roku Krajowy Plan Działania w zakresie energii ze źródeł odnawialnych ma skłonić do inwestowania w energetykę odnawialną, a także określić środki potrzebne do osiągnięcia celów pakietu klimatyczno-energetycznego. Zawarte w dokumencie dane sugerują osiągnięcie w 2020 roku celu z nadwyżką $0,5 \%$, dzięki energii cieplnej pozyskanej z odnawialnych źródeł (55\% energii wytwarzanej w źródłach OZE), odnawialnej energii elektrycznej (ok. 26\%) oraz biopaliwom (ok. 19\%) ${ }^{12}$. Stworzenie tego planu było dla państw członkowskich obligatoryjnym wymogiem Unii Europejskiej (Dyrektywa 2009/28/WE). Ma on ułatwić wzrost udziału OZE w energetyce, a także sprecyzować powzięte przedsięwzięcia w celu realizacji zadania „3×20”. Niestety Krajowy Plan Działania nie precyzuje dokładnie sposobów wsparcia, przepisów czy upraszczania procedur inwestycyjnych dla odnawialnych źródeł energii. Wspomina jedynie o powstaniu odrębnej ustawy dotyczącej OZE. Osiągnięcie celu pakietu klimatyczno-energetycznego przy wykorzystaniu Krajowego Planu Działania może okazać się więc niemożliwe, głównie przez brak przejrzystej informacji dla przedsiębiorców, którzy chcieliby inwestować w odnawialne źródła energii.

Porozumienie Polskiej Izby Gospodarczej Energii Odnawialnej, Polskiej Izby Biomasy, Stowarzyszenia Energii Odnawialnej oraz Stowarzyszenia Niezależnych Wytwórców Energii Skojarzonej doprowadziło do powstania dokumentu: Kierunki Rozwoju Biogazowni Rolniczych w Polsce na lata 2010-2020 (uchwała Rady Ministrów z dnia 13 lipca 2010 roku). Myślą przewodnią tego dokumentu jest prowadzenie inwestycji biogazowych, które mają doprowadzić do 2020 roku do powstania ok. 2000 biogazowni (średnio 1 biogazownia w gminie) ${ }^{13}$. W dokumencie tym przewiduje się, iż całkowita zainstalowana moc elektryczna pochodząca z biogazowni będzie wynosić $1 \mathrm{GW}$ (aktualnie wynosi $90 \mathrm{MW}$ ) ${ }^{14}$.

Polityka wobec odnawialnych źródeł energii nie może rozwijać się bez programów ją wspierających, a więc dotacji, dopłat oraz pożyczek. W Polsce organem odpowiedzialnym za te programy jest Narodowy Fundusz Ochrony Środowiska i Gospodarki Wodnej, który w latach 1989-2001 wydał kwotę 42 mld zł

11 Polityka Energetyczna Polski do 2030 roku...

12 Krajowy Plan Działania...

13 Ibidem.

14 Kierunki Rozwoju Biogazowni Rolniczych w Polsce na lata 2010-2020, Ministerstwo Gospodarki, Rada Ministrów z dnia 13 lipca 2010 r. 
na przedsięwzięcia ekologiczne ${ }^{15}$, które mają służyć $12 \mathrm{mln}$ obywateli ${ }^{16}$. Wsparcie Narodowego Funduszu kierowane jest do podmiotów prywatnych i publicznych, a instrumenty pomocy mogą przybierać następujące formy:

- inwestycyjnych lub nieinwestycyjnych dotacji,

- inwestycji kapitałowych,

- dopłat,

- oprocentowanych pożyczek,

- udzielanych przez banki kredytów pochodzących ze źródeł NFOŚiGW,

- umorzeń,

- częściowej spłaty kapitału kredytu,

- dopłat do oprocentowania lub ceny wykupu obligacji ${ }^{17}$.

W latach 2007-2013 dotacje pochodzące ze środków krajowych i unijnych oraz niskooprocentowane pożyczki okazały się najczęściej wykorzystywanymi formami wsparcia udzielanego przez NFOŚiGW ${ }^{18}$. Jednakże w latach 2014-2020 pożyczki niskooprocentowane mają dominować i stanowić $65 \%$ udziału we wszystkich formach wsparcia, a w 2020 roku dzięki funduszowi odnawialnemu mają osiągnąc $80 \%{ }^{19}$.

NFOŚiGW w latach 2007-2013 prowadził następujące programy wspierające rozwój inwestycji w odnawialne źródła energii:

- dopłaty ze środków krajowych, skierowane dla osób fizycznych oraz wspólnot mieszkaniowych na częściową spłatę kredytów bankowych (45\% kapitału kredytu), które zostały przeznaczone na zakup i montaż kolektorów słonecznych;

- system zielonych inwestycji GIS skierowany dla wytwórców energii elektrycznej i operatorów sieci energetycznych na inwestycje budowlane oraz modernizacyjne sieci elektroenergetycznych (o wartości inwestycji nie mniejszej niż $8 \mathrm{mln}$ zł) niezbędnych do podłączenia źródeł energii pochodzącej z wiatraków;

- dofinansowanie projektów (w kwotach od 170 tys. do 2 mln euro) dla jednostek sektora finansów publicznych i podmiotów realizujących zadania publiczne, ze środków norweskich, na promowanie OZE i oszczędzanie energii (poprzez np. termomodernizację budynków);

${ }_{15}$ M. Zabłocki, Potencjalne źródła finansowania inwestycji w odnawialne źródła energii w Polsce w latach 2007-2013 oraz w kontekście nowego horyzontu ekonomicznego, [w:] K. Pająk, A. Ziomek, S. Zwierzchlewski (red.), Ekonomia i zarządzanie energią a rozwój gospodarczy, Wydawnictwo Adam Marszałek, Toruń 2013, s. 164.

${ }^{16}$ Odnawialne źródto finansowania, Narodowy Fundusz Ochrony Środowiska i Gospodarki Wodnej, Warszawa 2012.

${ }^{17}$ www.nfosigw.gov.pl (dostęp: 20.08.2015).

${ }_{18}$ Finansowanie inwestycji energetycznych $w$ Polsce, PWC, ING, Warszawa 2011.

${ }_{19}$ M. Filipowicz, A. Figórski (red.), Finansowanie przedsięwzięć ekoenergetycznych dla wielu rozproszonych projektów. Pomyst na (energo)oszczędna gminę, Akademia Górniczo-Hutnicza, Kraków 2005, s. 125. 
- program pożyczek (od 4 do $50 \mathrm{mln}$ zł) wspierających przedsięwzięcia z zakresu OZE i obiektów wysokosprawnej kogeneracji ze środków krajowych - na ten cel przeznaczono 1,4 mld zł, a alokacja środków została już wyczerpana; - pożyczki z Wojewódzkich Funduszy Ochrony Środowiska i Gospodarki Wodnej dla podmiotów realizujących inwestycje w OZE;

- system zielonych inwestycji dla biogazowni rolniczych w formie dotacji i pożyczek;

- system zielonych inwestycji dla wykorzystujących biomasę elektrowni i elektrociepłowni;

- dotacje ze środków dla wysokosprawnego wytwarzania energii elektrycznej oraz ciepła, a także przebudowy i budowy obiektów produkujących energię elektryczną;

- dofinansowania w zakresie wód geotermalnych ${ }^{20}$.

We wrześniu 2012 roku została przyjęta Strategia Działania Narodowego Funduszu Ochrony Środowiska i Gospodarki Wodnej na lata 2013-2016 z perspektywami do 2020 roku, której aktualizacja nastąpiła w lipcu 2015 roku. Strategia ta ma na celu przyśpieszenie oraz usprawnienie gospodarowania funduszami krajowymi oraz zagranicznymi, co umożliwia szybsze inwestycje w OZE. Jej hasłem przewodnim jest: „Narodowy Fundusz Ochrony Środowiska i Gospodarki Wodnej - liderem finansowania ochrony środowiska i gospodarki wodnej w Polsce - nastawiony na EFEKT". Na finansowanie tych celów w latach 2015-2023 Narodowy Fundusz przeznaczy kwotę 18,3 mld $\mathrm{z}^{21}$.

Z zadań w ramach Priorytetu III - Ochrona Atmosfery, na które m.in. przeznaczone są wspomniane wyżej środki finansowania, możemy wyróżnić programy dotyczące:

- przedsięwzięć w zakresie OZE i obiektów wysokosprawnej kogeneracji,

- wykorzystywania zasobów geotermalnych w celach energetycznych,

- wyższej efektywności energetycznej,

- opracowywania programów na rzecz ochrony środowiska oraz planów ich działania,

- wzrostu udziału i rozwoju rozproszonych odnawialnych źródeł energii,

- inteligentnych sieci energetycznych,

- systemu zielonych inwestycji ${ }^{22}$.

Strategia działań ma na celu uaktywnienie podmiotów gospodarczych do inwestowania w polski potencjał odnawialnych źródeł energii, których wykorzystanie nadal pozostaje na niewysokim poziomie. Jest to szansa dla poszczególnych

${ }^{20}$ Narodowy Fundusz Ochrony Środowiska i Gospodarki Wodnej, 2013 r. (dostęp 20.08.2015)

${ }_{21}^{21}$ Strategia Działania Narodowego Funduszu Ochrony Środowiska i Gospodarki Wodnej na lata 2013-2016 z perspektywami do 2020 roku, aktualizacja, lipiec, Warszawa 2015.

22 Strategia Działania Narodowego Funduszu Ochrony Środowiska i Gospodarki Wodnej na lata 2013-2016 z perspektywami do 2020 roku, wrzesień, Warszawa 2012, s. 51-52. 
regionów (głównie województw mazowieckiego i śląskiego ${ }^{23}$, dla których przewidziane są największe środki finansowe) na promocję i rozwój inwestycji w OZE. Może także przynieść korzyści ekonomiczne (np. rozwój przedsiębiorstw, wyższe wpływy z podatków, zwiększenie niezależności energetycznej), społeczne (np. większa świadomość społeczeństwa) i środowiskowe (np. mniejsze negatywne oddziaływanie na środowisko).

Ogłoszona 3 kwietnia 2015 roku Ustawa o odnawialnych źródłach energii to szansa dla Polski na spełnienie wymogów postawionych przez Unię Europejską osiągnięcie 15\% udziału OZE w konsumpcji finalnej do 2020 roku. Ustawa umożliwia nie tylko zwiększenie wykorzystywania odnawialnych źródeł energii, ale także sprzyja rozwojowi budownictwa energooszczędnego. Ponadto pozwala przedsiębiorstwom i gospodarstwom domowym na odsprzedaż nadwyżek energetycznych.

\section{Odnawialne źródła energii w japońskim systemie energetycznym}

Energia odnawialna w Japonii w głównej mierze pozyskiwana jest z elektrowni wodnych. Dotychczas znikomy udział mają elektrownie słoneczne i wiatrowe. W ostatnich latach można zauważyć znaczny wzrost udziału biomasy w produkcji czystej energii elektrycznej. Problemem, z którym musi zmierzyć się japoński rząd, jest niewątpliwie dominacja ok. 10 firm związanych z produkcją energii elektrycznej, które zgodnie z japońskim prawem energetycznym (Electricity Business Law) stosują zasadę „odpowiednich kosztów” oraz „odpowiednich zysków”24. Taka polityka w żaden sposób nie wpływa na podwyższenie efektywności produkcji energii elektrycznej przez przedsiębiorstwa, ponieważ dzięki swoistej manipulacji cenowej koszty produkcyjne (czasem również promocyjne ${ }^{25}$ ) przenoszone są na odbiorców (mieszkańców oraz przedsiębiorstwa) ${ }^{26}$.

Według raportu (2012) sporządzonego przez komisję parlamentarną zajmującą się ,incydentem w Fukushimie” przyczyn tej katastrofy upatruje się w japońskich uwarunkowaniach kulturowych, zgodnie z którymi, równość obywateli oznacza brak „wybijania” się jednostek, istnienie obaw przed podważaniem autorytetów, a także uporczywe postępowanie zgodnym z przepisami. Ponadto wytknięto zbyt wysoki wpływ gigantycznych przedsiębiorstw energetycznych na japoński rząd, co

${ }^{23}$ G. Wiśniewski, Określenie potencjatu energetycznego regionów Polski w zakresie odnawialnych źródet energii - wnioski dla Regionalnych Programów Operacyjnych na okres programowania 2014-2020, Instytut Energetyki Odnawialnej, Warszawa 2011.

${ }^{24}$ Zasady te polegają na stanowieniu cen przez przedsiębiorstwa za energię elektryczną, umożliwiających zysk na poziomie wyższym niż wynoszą koszty operacyjne.

${ }^{25}$ Doskonałym przykładem „marnotrawienia” pieniędzy odbiorców jest niemająca konkurentów firma TEPCO, która w 2010 roku wydała na promocję reklamową blisko 12 mld jenów.

26 J. Malko, Energetyka japońska: jak radykalna transformacja, „Energetyka” 2013, nr 5. 
uniemożliwiło wprowadzenie szerszych regulacji ${ }^{27}$ oraz prawa dotyczących sektora energetycznego. Spowodowało to utrudnienia dla nowych przedsiębiorstw energetycznych, które chciałyby wejść na rynek energii. Jest to w głównej mierze związane z tym, iż monopolistyczne przedsiębiorstwa energetyczne, oprócz produkcji energii elektrycznej, posiadają również sieci dystrybucyjne oraz przesyłowe w regionie swojej działalności, co w większości uniemożliwia powstawanie nowych przedsiębiorstw energetycznych, dla których barierą jest zbyt wysoki kapitał początkowy ${ }^{28}$.

Na podstawie wspomnianego raportu, a także w związku z coraz bardziej nasilającym się sprzeciwem wobec energetyki jądrowej (aż 22\% Japończyków opowiedziało się za całkowitym usunięciem elektrowni atomowych) ${ }^{29}$ japoński rząd opracował dokument „Opcje dla energii i środowiska” (22 czerwca 2012 roku). Rewolucja elektroenergetyczna ma zajść dzięki wytyczeniu kierunków postępowania „po Fukushimie” poprzez cztery główne obszary tematyczne.

Pierwszym obszarem jest wprowadzenie nowych środków bezpieczeństwa dla elektrowni atomowych w całym cyklu ich funkcjonowania, a także zmiany w systemie zarządzania nimi. Rząd przy współpracy z NRA (Nuclear Regulation Authority - Agencja Dozoru Jądrowego) nakazał sprawdzenie bezpieczeństwa instalacji jądrowych, które polega na zbadaniu sejsmiczności terenów, na których zlokalizowane są elektrownie atomowe ${ }^{30}$, oraz wprowadzenie dodatkowych zabezpieczeń przed zalaniem (poprzez uszczelnianie pomieszczeń) przez tsunami ${ }^{31}$. Dopiero po przeprowadzeniu szczegółowych badań przedsiębiorstwo energetyczne może zwrócić się do rządu z prośbą o możliwość ponownego włączenia zbadanych reaktorów. Wykonanie tych zadań ma sprzyjać zabezpieczeniu kraju przed energetyką wysokiego ryzyka. Na skutek tragedii fukushimskiej część ludności oraz przedsiębiorstw była odcięta od regularnych dostaw prądu. Ukazało to niedoskonałość linii przesyłowych w kraju, które nieprzystosowane były do przesyłu zwiększonej ilości energii elektrycznej (było to w głównej mierze spowodowane tym, iż przedsiębiorstwa energetyczne mają ściśle określone wielkości przesyłu dla regionów, w których operują). Doprowadziło to do zwiększenia troski rządu o bezpieczeństwo energetyczne kraju - istotność tegoż bezpieczeństwa wytyczyła drugi obszar zmian. Ma on polegać na proporcjonalnej zamianie energii jądrowej na inne formy pozyskiwania energii poprzez kompatybilne i zdywersyfikowane wykorzystywanie surowców energetycznych. Kolejnym obszarem tematycznym

27 Regulacje związane są głównie z wprowadzeniem tzw. Czwartej Fazy deregulacji sektora energetycznego z 2007 roku, co się nie powiodła.

28 J. Malko, Energetyka japońska...

${ }^{29} \mathrm{http} / /$ www.world-nuclear.org/info/Country-Profiles/Countries-G-N/Japan/\#.UjcMAibwG70 (dostęp: 10.07.2015 r.).

${ }^{30}$ Badanie zdarzeń sprzed ostatnich 120 tys. lat, a w szczególnych, wątpliwych wypadkach sprzed 400 tys. lat.

31 A. Rajewski, Japonia bez atomu - co najmniej do grudnia, http://adamrajewski.natemat. pl/75005,japonia-ponownie-bez-atomu (dostęp: 10.07.2015). 
jest ograniczenie emisji $\mathrm{CO}_{2}$, przy jednoczesnym zmniejszeniu wykorzystania energii atomowej. Założenie to wydaje się irracjonalne, jednakże przy zastosowaniu najnowocześniejszych technologii możliwe jest zwiększenie udziału energetyki opartej na węglu, przy jednoczesnej redukcji emisji dwutlenku węgla. Japoński rząd, pomimo dużego wykorzystania surowców kopalnych, zakłada zmniejszenie emisji gazów o $80 \%$ do 2050 roku. Osiągnięciu tego celu ma sprzyjać wprowadzenie w październiku 2012 roku podatku węglowego ${ }^{32}$. Dużym problemem dla Japonii są wysokie koszty energii elektrycznej, które powodują przenoszenie przedsiębiorstw przemysłowych w miejsca, gdzie koszty prowadzenia działalności są mniejsze. Czwarty obszar działania obejmuje prace nad zmniejszeniem tych kosztów i przeciwdziałanie nierównomiernej lokalizacji przedsiębiorstw (elektrowni), a także proporcjonalne zapewnienie miejsc pracy i możliwości biznesowych dla japońskich obywateli.

Realizacja wyżej wymienionych zadań ma sprzyjać ograniczeniu (bądź całkowitej redukcji) energii atomowej oraz zmniejszeniu udziału energetyki węglowej na rzecz odnawialnych źródeł energii w bilansie energetycznym kraju do 2030 roku. Duży wzrost udziału OZE miał miejsce w 2014 roku (zmiana o $1,8 \%$ w stosunku do 2013 roku). Dodatkowo w planie przewidywana jest poprawa efektywności energetycznej, przy jednoczesnej redukcji emisji $\mathrm{CO}_{2}$. Według przewidywań Instytutu Zrównoważonej Polityki Energetycznej Japonii energia atomowa powinna pokrywać zaledwie 5\% krajowego zapotrzebowania na energię, odnawialne źródła energii ok. 30-35\%, natomiast paliwa kopalne $60-65 \%{ }^{33}$.

Wymienione zmiany uzupełnione są o stworzenie podstaw do przeprowadzenia reform strukturalnych, które miałyby skutkować rozdzieleniem zrzeszonych, regionalnych przedsiębiorstw energetycznych, co sprzyjałoby otwarciu się rynku detalicznego i stworzeniu ułatwień dla wejścia na rynek gospodarstw domowych oraz małych przedsiębiorstw. W oparciu o raport „Opcje dla energii i środowiska” utworzono dla sektora energii elektrycznej trzy możliwe scenariusze (tab. 1).

W japońskiej energetyce $\mathrm{w}$ dalszym ciągu duży udział będzie miała jednak energia pochodząca z atomu. Już w 2012 roku miało miejsce pierwsze, po wydarzeniach z 2011 roku, otwarcie elektrowni atomowej w Ohi, co miało na celu zapewnienie bezpieczeństwa energetycznego regionu Osaki. W związku z owymi wydarzeniami ówczesny premier Yoshihiko Noda wydał oświadczenie: „Tania i stabilna energia elektryczna jest sprawą podstawową. Jeżeli wszystkie reaktory, które zaspokajały uprzednio 30\% krajowego zapotrzebowania, zostaną zatrzymane, to społeczeństwo Japonii nie przetrwa". Postawa ta zasygnalizowała dążenia japońskiego rządu do utrzymania wykorzystywania energii atomowej. Zostało to

${ }^{32}$ U. Drabińska, Co zrobia państwa dla klimatu? Przegląd ustawodawstwa na świecie, http:// www.chronmyklimat.pl/opinie/polityka-klimatyczna/co-robia-panstwa-dla-klimatu-przeglad-ustawodawstwa-na-swiecie (dostęp: 10.07.2015).

${ }^{33}$ Malko J., Energetyka japońska... 
przypieczętowane powrotem na stanowisko premiera Shinizo Abe, który zapowiedział powolne przywracanie pracy reaktorów atomowych.

Tabela 1. Struktura energetyczna („,energy mix”) Japonii dla trzech proponowanych scenariuszy do 2030 roku

\begin{tabular}{|l|c|c|c|c|c|}
\hline \multicolumn{1}{|c|}{ Wyszczególnienie } & \multirow{2}{*}{ Rok 2010 } & Opcja 1 & Opcja 2 & Opcja 3 & $\begin{array}{c}\text { Aktualny } \\
\text { Plan Strategii } \\
\text { Elektrycznej } \\
\text { dla Japonii }\end{array}$ \\
\cline { 2 - 6 } & & $\begin{array}{c}\text { Scenariusz } \\
\mathbf{0} \%\end{array}$ & $\begin{array}{c}\text { Scenariusz } \\
\mathbf{1 5 \%}\end{array}$ & $\begin{array}{c}\text { Scenariusz } \\
\mathbf{2 0 - 2 5 \%}\end{array}$ & Do 2030 roku \\
\hline energia nuklearna & $26 \%$ & $0 \%$ & $15 \%$ & $20-25 \%$ & $45 \%$ \\
\hline OZE & $10 \%$ & $35 \%$ & $30 \%$ & $25-30 \%$ & $20 \%$ \\
\hline paliwa kopalne & $63 \%$ & $65 \%$ & $65 \%$ & $50 \%$ & $35 \%$ \\
\hline $\begin{array}{l}\text { udział zasobów } \\
\text { odnawialnych }\end{array}$ & $37 \%$ & $30 \%$ & $45 \%$ & $50 \%$ & $65 \%$ \\
\hline $\begin{array}{l}\text { produkcja energii } \\
\text { elektrycznej }\end{array}$ & $1100 \mathrm{ThW}$ & $1000 \mathrm{ThW}$ & $1000 \mathrm{ThW}$ & $1000 \mathrm{ThW}$ & $1200 \mathrm{ThW}$ \\
\hline $\begin{array}{l}\text { końcowe zużycie energii } \\
\text { elektrycznej }\end{array}$ & 390 & 310 & 300 & 310 & 340 \\
\hline $\begin{array}{l}\text { emisje gazów cieplarnianych } \\
\text { w porównaniu do 1996 r. }\end{array}$ & $-0,3 \%$ & $-16 \%$ & $-23 \%$ & $-25 \%$ & ok. -30\% \\
\hline
\end{tabular}

Źródło: J. Malko, Energetyka japońska: jak radykalna transformacja?, , Energetyka” 2013, nr 5.

Polityka i regulacje wprowadzone przez japoński rząd w 2011 roku oraz szeroka kampania społeczna nakłaniająca japońskie społeczeństwo oraz podmioty gospodarcze do ograniczenia zużycia energii elektrycznej okazały się skuteczne. Niewielkie zmiany i proste procedury, takie jak wymiana żarówek na energooszczędne, wyłączanie zbędnego światła i świecących banerów reklamowych oraz ruchomych schodów, a także ograniczenie używania klimatyzatorów, pozwoliło latem 2011 roku na ograniczenie zużycia energii o jedną piątą ${ }^{34}$. Dowodzi to, iż japoński rząd zastosował skuteczną politykę zwalczającą braki energetyczne w kraju po tragedii w Fukushimie.

Japońska polityka wobec odnawialnych źródeł energii obejmuje:

- stosowanie dotacji finansowych dla przedsięwzięć OZE,

- zachęcanie przedsiębiorstw energetycznych do włączania OZE,

- program odkupywania energii elektrycznej po stałej cenie.

${ }^{34}$ P. Siergiej, Japonia zastępuje atom negawatami, http://www.chronmyklimat.pl/wideo/zielona-gospodarka/japonia-zastepuje-atom-negawatami (dostęp: 10.07.2015). 
Stosowanie dotacji wspomagających przedsiębiorstwa energetyczne zostało wprowadzone na podstawie ustawy o promocji wykorzystywania nowej energii z 1997 roku. Jest ono realizowane poprzez zapewnianie częściowego finansowania przedsięwzięć w ramach „,nowej energii” dla prywatnych przedsiębiorstw, a także gwarancję dla kredytów zaciągniętych w instytucjach finansowych przez te przedsiębiorstwa. Dodatkowo ustawa ta gwarantuje samorządom lokalnym pomoc finansową na projekty związane z budową i rozwojem nowej energii, a także atrakcyjne podatki i subsydia dla krajowych i międzynarodowych firm rozwijających ekologiczną aktywność w poszczególnych regionach ${ }^{35}$.

Prowadzenie polityki zachęt dla przedsiębiorców z sektora energetycznego dla zwiększania udziału OZE w ogólnej ich produkcji energii elektrycznej przypadło na lata 2003-2012. Zgodnie z prawem Renewable Portfolio Standard (RPS) przedsiębiorstwa energetyczne zobligowane były do wykorzystywania energii elektrycznej z OZE w odpowiedniej proporcji do rocznej sprzedaży. Przedsiębiorstwa owe standardy mogły wprowadzić na trzy sposoby:

- wytwarzanie energii elektrycznej z OZE we własnych strukturach,

- wykupywanie energii elektrycznej z OZE od innych producentów,

- wykupienie tzw. Certyfikatów Nowej Energii ${ }^{36}$.

Jednakże prawo to nie przyniosło spektakularnych wyników, głównie ze względu za niewystarczające (zbyt niski wymóg udziału OZE w ogólnej produkcji) dopasowanie obligatoryjnych wskaźników dla przedsiębiorstw.

Działający od 2009 roku program wsparcia dla odkupywania nadwyżek energii po cenach stałych gwarantuje przedsiębiorstwom całkowity zakup czystej energii elektrycznej ${ }^{37}$. Ponadto zainaugurował on wprowadzenie taryf gwarantowanych (FIT) przydzielanych od 2012 roku podmiotom sprzedającym energię elektryczną ze źródeł odnawialnych po ustalonych cenach. Sprawność tego systemu uzależniona jest od atrakcyjności ceny, bowiem kluczem do sukcesu jest odnalezienie równowagi pomiędzy popularyzacją OZE a kwotą, którą musi zapłacić konsument. Jeśli będzie ona zbyt niska, nie będzie zachęcać przedsiębiorców do inwestowania w OZE i nie doprowadzi do szerszego ich wykorzystania. Jednakże jeśli będzie zbyt wygórowana, konsument zostanie zmuszony do zbyt dużej zapłaty, tak więc dofinansowanie projektu będzie dla niego zbyt kosztowne - nieopłacalne. Rząd japoński powołał więc komisję odpowiedzialną za ustalenie adekwatnych cen.

Wprowadzony w kwietniu 2014 roku Nowy Strategiczny Plan Energetyczny obejmuje następujące zagadnienia:

- bezpieczeństwo energetyczne,

- efektywność energetyczną,

${ }^{35}$ K. Jetro, E. Feinstein, Cleantech Opportunities in Japan, JETRO, San Francisco 2012.

36 J. Edahiro, Japan Begins Feed-in Tariff Shame to Accelerate Renewable Energy Promotion, JFS Newsletter No. 110, November 8th 2011.

37 J. Edahiro, Japan Begins... 


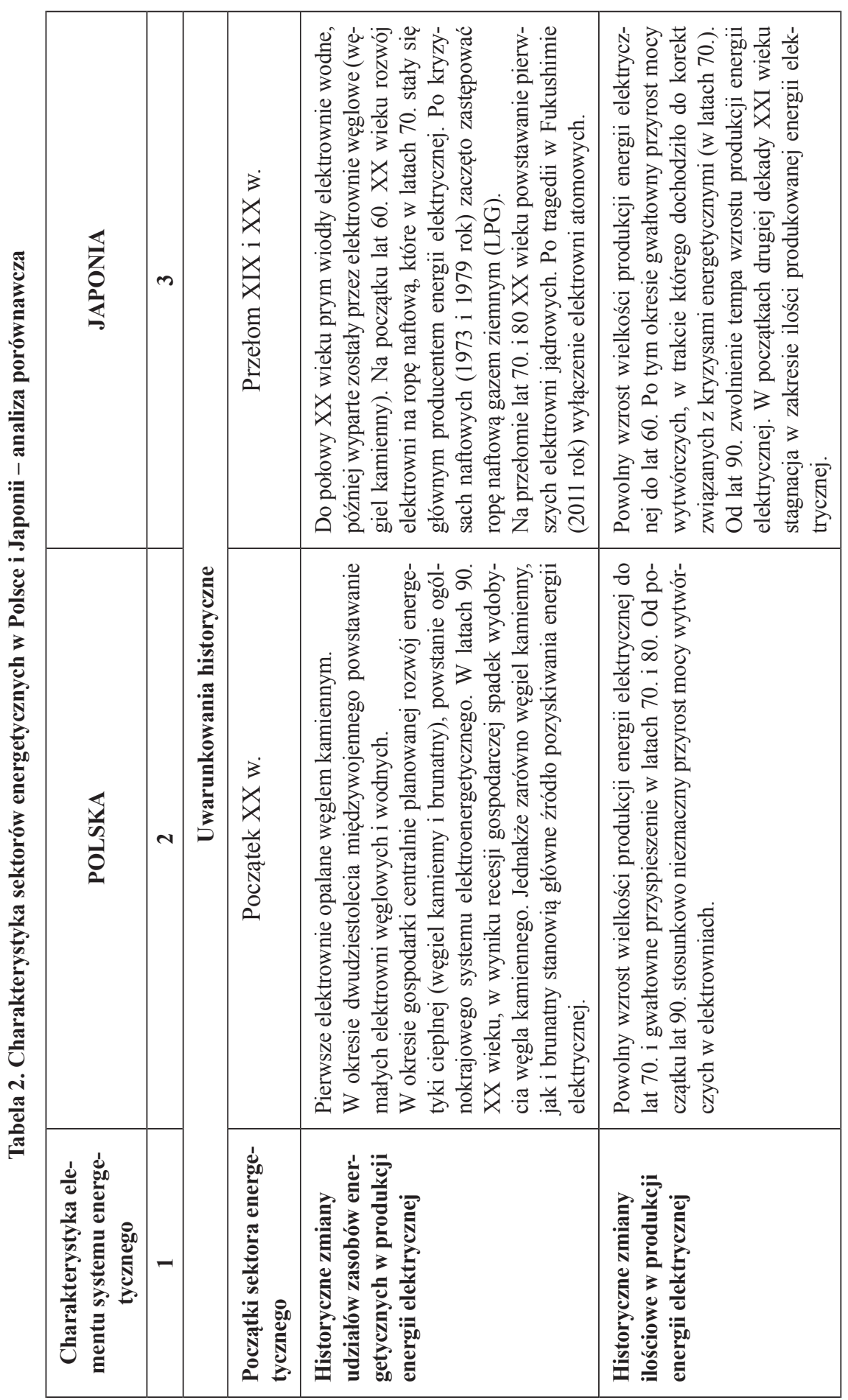




\begin{tabular}{|c|c|c|c|c|c|}
\hline m & 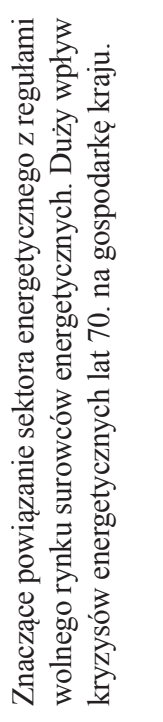 & & 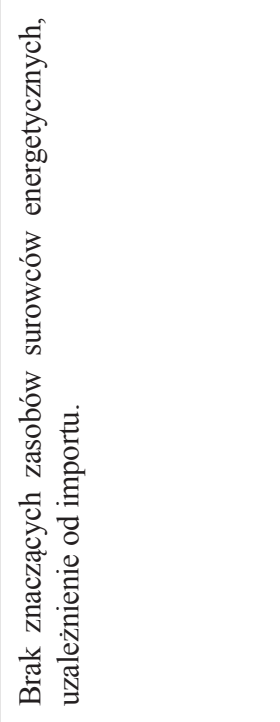 & 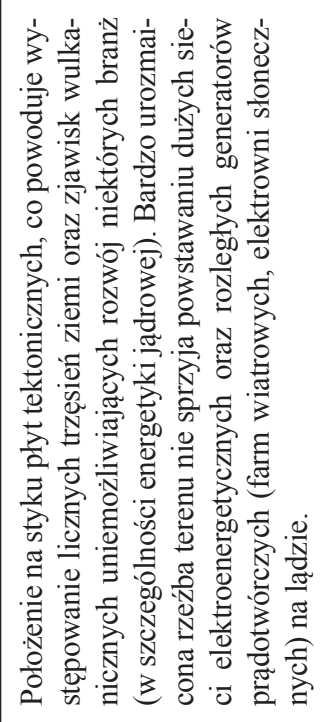 & 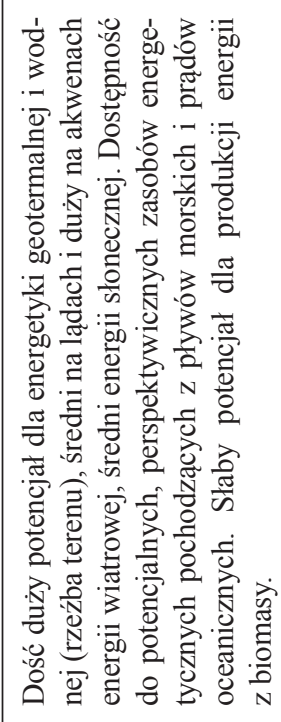 \\
\hline$N$ & 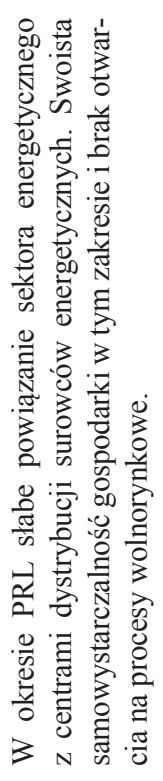 & 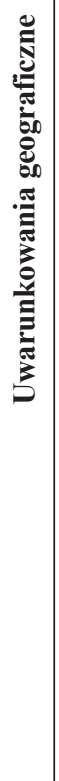 & 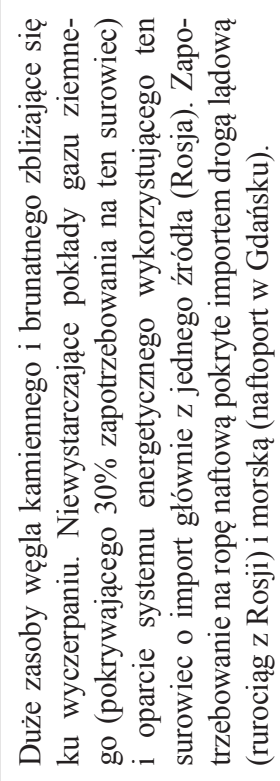 & 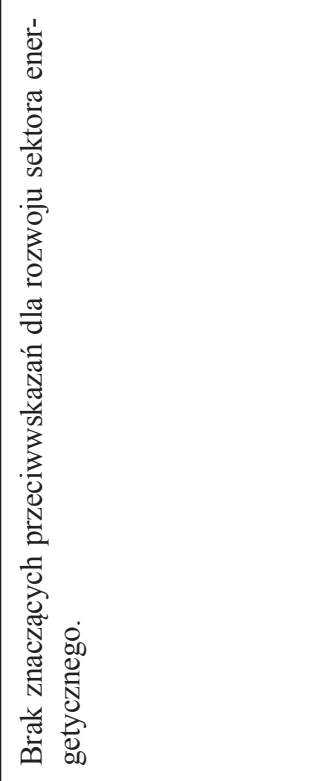 & 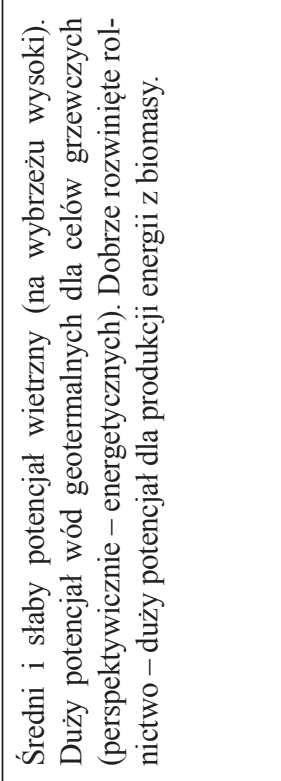 \\
\hline-1 & 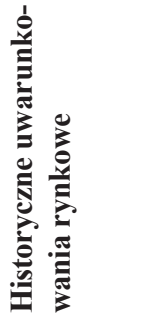 & & 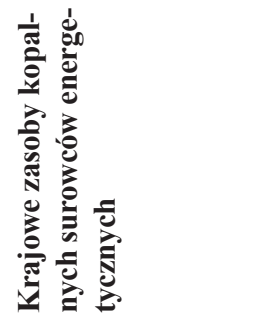 & 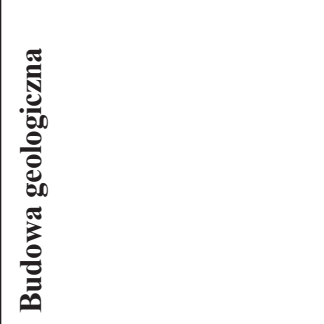 & 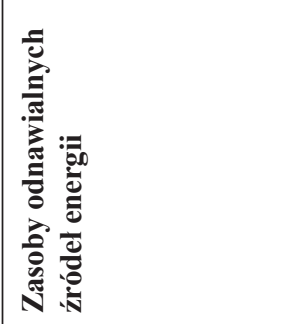 \\
\hline
\end{tabular}




\begin{tabular}{|c|c|c|c|c|c|c|c|c|}
\hline 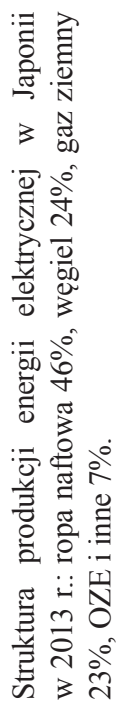 & \multirow{3}{*}{ 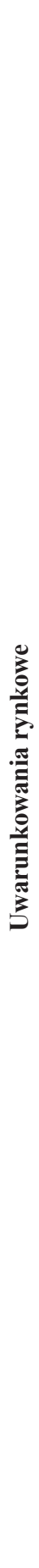 } & 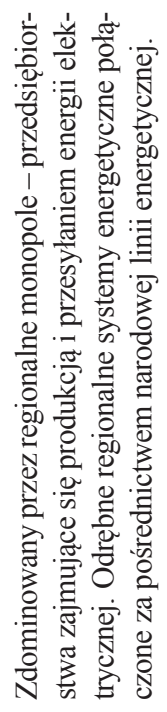 & 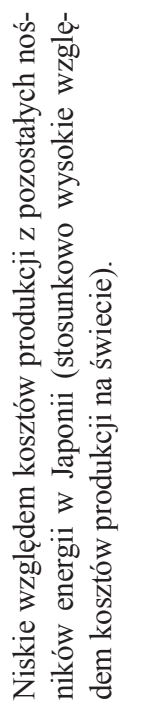 & 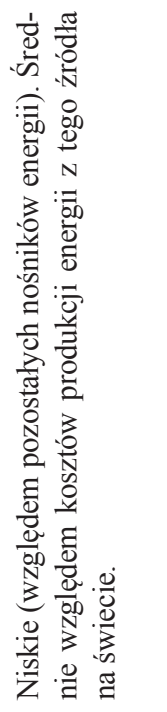 & 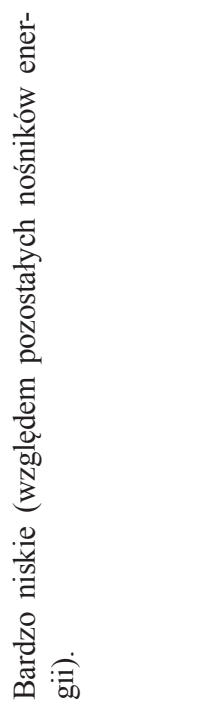 & 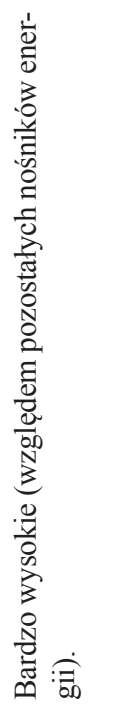 & \multirow{3}{*}{ 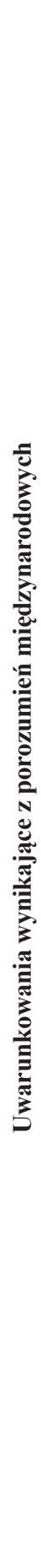 } & 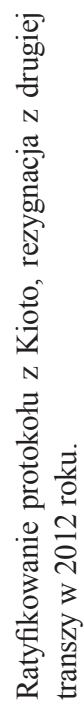 \\
\hline 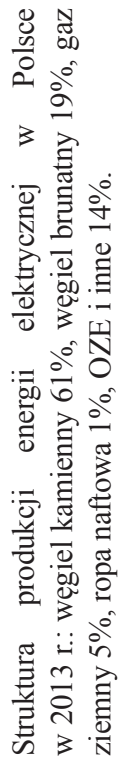 & & 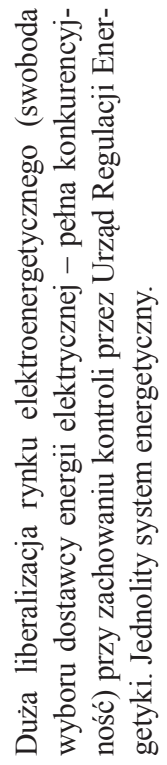 & 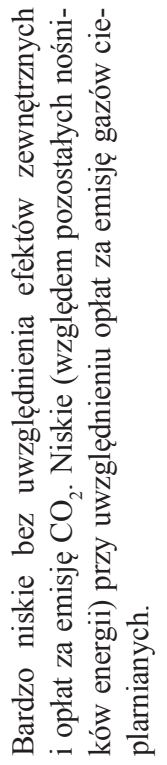 & 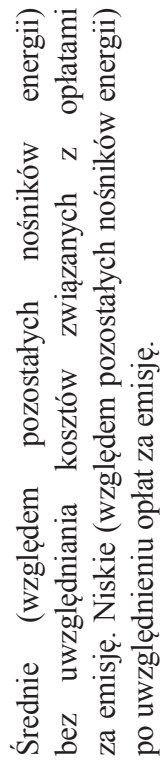 & 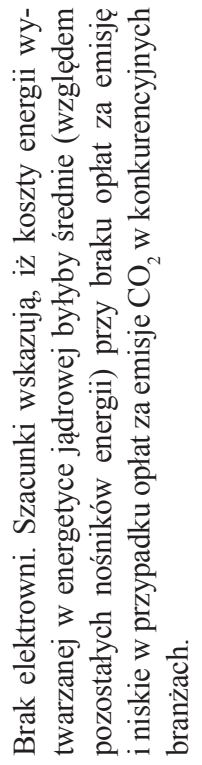 & 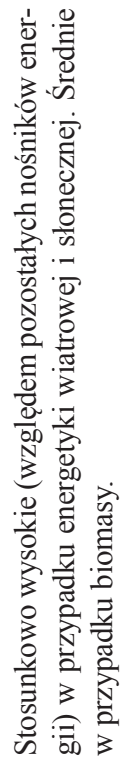 & & 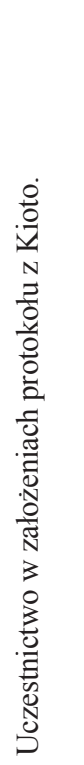 \\
\hline 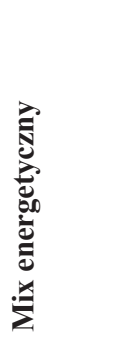 & & 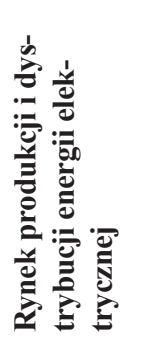 & 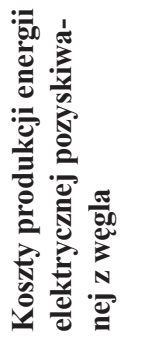 & 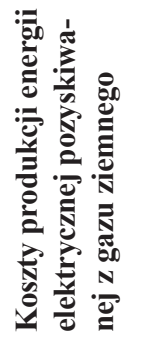 & 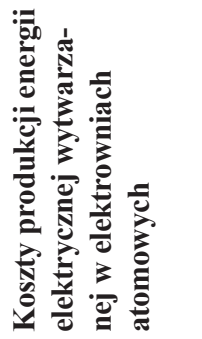 & 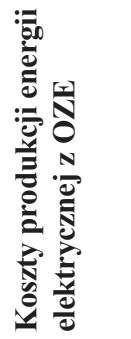 & & 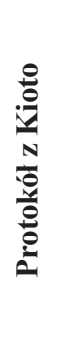 \\
\hline
\end{tabular}




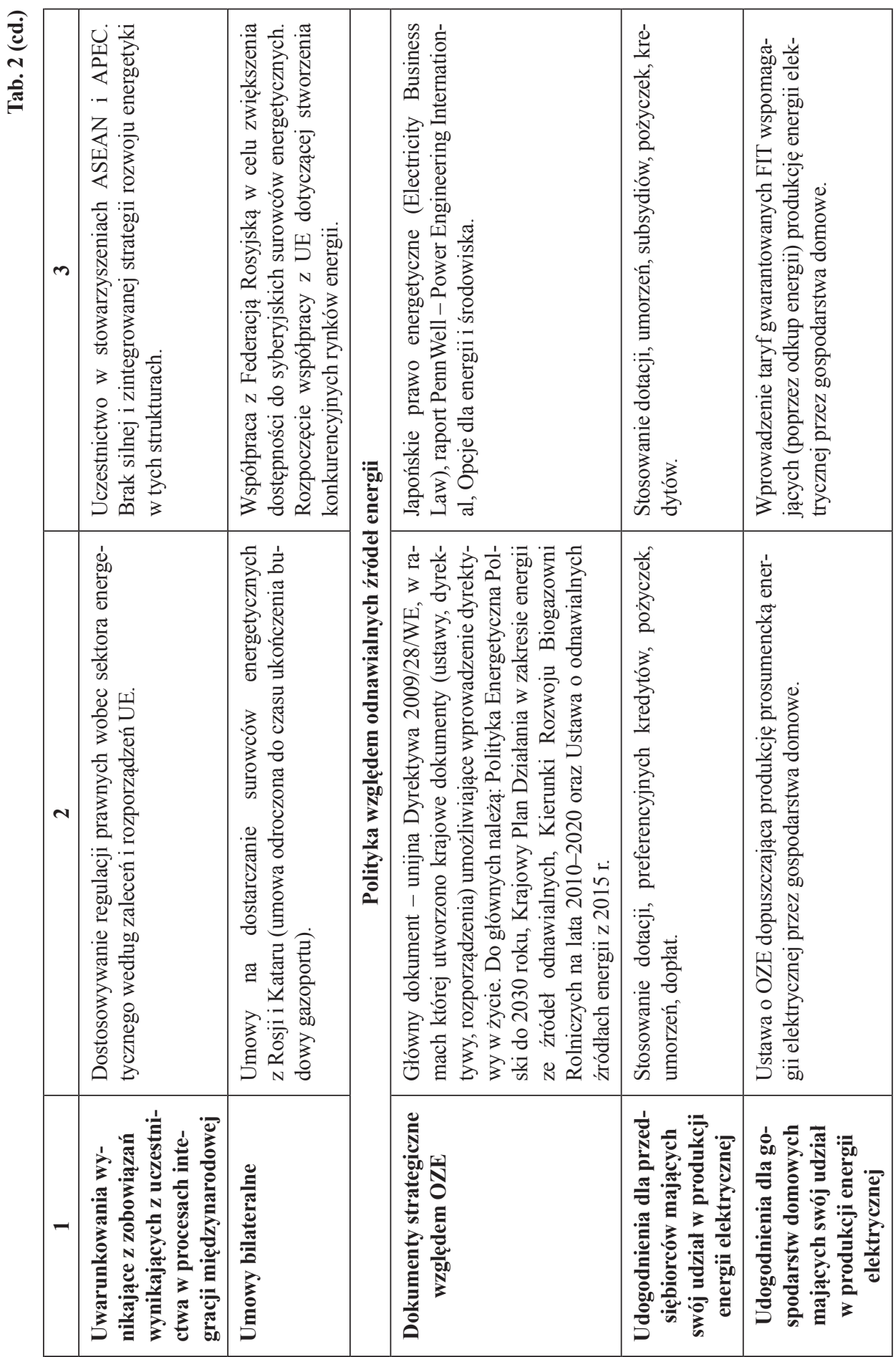


- środowisko,

- globalne spojrzenie na energetykę,

- wzrost ekonomiczny ${ }^{38}$.

Plan ma za zadanie wytyczanie kierunków działań średnio- i długookresowych dla polityki energetycznej Japonii, a także przeprowadzenie licznych reform usprawniających działalność sektora energetycznego. Głównym celem planu jest jak najszybsze upowszechnienie wykorzystania OZE ${ }^{39}$.

\section{Analiza porównawcza sektorów energetycznych Polski i Japonii}

Analizę porównawczą sektorów energetycznych w Polsce i Japonii z uwzględnieniem odnawialnych źródeł energii zawiera tabela 2.

\section{Zakończenie}

Rozwój energetyki w Polsce przypadł na XX wiek, głównie opierając się na krajowych zasobach węgla kamiennego i brunatnego. Początki działalności sektora energetycznego w Japonii przypadają na przełom XIX i XX wieku. W przeciwienstwie do Polski, struktura produkcji energii elektrycznej w Japonii na przestrzeni lat w znaczącym stopniu ulegała zmianie. Wiąże się to w głównej mierze z warunkami naturalnymi panującymi w obu krajach, bogactwem surowców naturalnych, które determinowały niezależność kraju. Polska dzięki dużym pokładom węgla stała się gospodarką samowystarczalną energetycznie. Japonia natomiast, w wyniku braku surowców energetycznych, uzależniona była od importu, co sprzyjało zmianie struktury energetyki.

Obecnie polski sektor energetyczny w dużej mierze regulowany jest przez ustawodawstwo Unii Europejskiej. Wiąże się to z dostosowywaniem polityki energetycznej oraz koniecznością spełniania wymogów stawianych przez UE. Podlega procesowi liberalizacji i działa w ramach jednolitego systemu energetycznego. Energetyka w Japonii jest zdominowana przez monopole, które działają w ramach regionalnych systemów energetycznych połączonych narodową linią energetyczną. Japonia po katastrofie w Fukushimie zmieniła politykę, która w dużej mierze ma umożliwić osiągnięcie wysokiego udziału OZE w strukturze energetycznej kraju, przy jednoczesnym ograniczeniu produkcji energii atomowej.

Oba kraje prowadzą politykę umożliwiającą rozwój przedsiębiorstw energetycznych inwestujących w odnawialne źródła energii. Głównymi sposobami

${ }^{38}$ T. Kashiwagi, Strategic Energy Plan of Japan. Focus on Energy System Reform of Japan and Building Smart Community, Tokyo Institute of Technology, Tokyo 2014.

${ }^{39}$ Ibidem. 
zachęcenia przedsiębiorców są dotacje, umorzenia, pożyczki oraz preferencyjne kredyty. Ponadto, dzięki ustawie o OZE w Polsce oraz wprowadzeniu taryf gwarantowanych FIT w Japonii, możliwy jest rozwój samowystarczalnych energetycznie gospodarstw domowych, mających prawo odsprzedaży nadwyżek wyprodukowanej energii.

W strukturach obu państw coraz większy udział w wytwarzaniu energii elektrycznej mają odnawialne źródła energii. W 2013 roku w Polsce stanowiły one $14 \%$ ogólnej produkcji, w Japonii 7\%. Przy obecnym poziomie rozwoju technologicznego, a także udogodnieniach dla przedsiębiorców możliwy jest dalszy rozwój odnawialnych źródeł energii w tych krajach. Podsumowując, rozwój branży energetycznej w obu krajach uzależniony jest od rzetelności w wypełnianiu przyjętych wcześniej przez oba kraje założeń.

\section{Bibliografia}

Drabińska U., Co zrobia państwa dla klimatu? Przeglad ustawodawstwa na świecie, http://www. chronmyklimat.pl/opinie/polityka-klimatyczna/co-robia-panstwa-dla-klimatu-przeglad-ustawodawstwa-na-swiecie (dostęp: 10.07.2015 r.).

Edahiro J., Japan Begins Feed-in Tariff Shame to Accelerate Renewable Energy Promotion, JFS Newsletter, No. 110, November 8th 2011.

Feinstein E., Cleantech Opportunities in Japan, JETRO, San Francisco 2012.

Filipowicz M., Figórski A. (red.), Finansowanie przedsięwzięć ekoenergetycznych dla wielu rozproszonych projektów. Pomyst na (energo)oszczędna gminę, Akademia Górniczo-Hutnicza, Kraków 2005.

Finansowanie inwestycji energetycznych w Polsce, PWC, ING, Warszawa 2011.

Gawlik L., Mokrzycki E., Uliasz-Bocheńczyk A., Potencjat odnawialnych źródeł energii w Polsce, [w:] Tarajkowski J. (red.), Czynnik ENERGIA w polityce gospodarczej, Wydawnictwo Poznańskie Towarzystwo Przyjaciół Nauk, Poznań 2010.

Kashiwagi T., Strategic Energy Plan of Japan. Focus on Energy System Reform of Japan and Building Smart Community, Tokyo Institute of Technology, Tokyo 2014.

Kierunki Rozwoju Biogazowni Rolniczych w Polsce na lata 2010-2020, Ministerstwo Gospodarki, Rada Ministrów z dnia 13 lipca 2010 r.

Krajowy Plan Działania w zakresie energii ze źródeł odnawialnych, Ministerstwo Gospodarki, Rada Ministrów z dnia 10 grudnia $2010 \mathrm{r}$.

Malko J., Energetyka japońska: jak radykalna transformacja?, „Energetyka” 2013, nr 5.

Odnawialne źródło finansowania, Narodowy Fundusz Ochrony Środowiska i Gospodarki Wodnej, Warszawa 2012.

Polityka Energetyczna Polski do 2030 roku, Uchwała Rady Ministrów nr 202/2009 z dnia 10 listopada $2009 \mathrm{r}$.

Rajewski A., Japonia bez atomu - co najmniej do grudnia, http://adamrajewski.natemat.pl/75005, japonia-ponownie-bez-atomu (dostęp: 10.07.2015).

Siergiej P., Japonia zastępuje atom negawatami, http://www.chronmyklimat.pl/wideo/zielona-gospodarka/japonia-zastepuje-atom-negawatami (dostęp: 10.07.2015).

Strategia Działania Narodowego Funduszu Ochrony Środowiska i Gospodarki Wodnej na lata 2013-2016 z perspektywami do 2020 roku, Warszawa, wrzesień 2012. 
Strategia Działania Narodowego Funduszu Ochrony Środowiska i Gospodarki Wodnej na lata 2013-2016 z perspektywami do 2020 roku, aktualizacja, Warszawa, lipiec 2015.

Ustawa o odnawialnych źródłach energii z dnia 20 lutego 2015 r., Dz.U. 2015, poz. 478.

Wiśniewski G., Określenie potencjału energetycznego regionów Polski w zakresie odnawialnych źródet energii - wnioski dla Regionalnych Programów Operacyjnych na okres programowania 2014-2020, Instytut Energetyki Odnawialnej, Warszawa 2012.

Zabłocki M., Potencjalne źródła finansowania inwestycji w odnawialne źródta energii w Polsce w latach 2007-2013 oraz w kontekście nowego horyzontu ekonomicznego, [w:] Pająk K., Ziomek A., Zwierzchlewski S. (red.), Ekonomia i zarządzanie energia a rozwój gospodarczy, Wydawnictwo Adam Marszałek, Torun 2013.

www.nfosigw.gov.pl (dostęp: 10.07.2015).

www.PowerEngineeringint.com (dostęp: 10.07.2015).

www.world-nuclear.org/info/Country-Profiles/Countries-G-N/Japan/\#.UjcMAibwG70 (dostęp: 10.07.2015).

\section{Streszczenie}

W dobie globalizacji i coraz większej świadomości konsumentów dotyczącej troski o środowisko naturalne ważnym czynnikiem jest wdrażanie proekologicznych i zrównoważonych instalacji w celu ograniczenia negatywnego wpływu działalność ludzkiej na środowisko. Punktem zwrotnym troski o „czystą planetę” jest wykorzystywanie odnawialnych źródeł energii i zwiększenie ich udziału w całkowitym zużyciu energii elektrycznej. Celem artykułu jest analiza porównawcza uwarunkowań rozwoju energetyki odnawialnej w Polsce i Japonii. Pomimo deklarowanego zainteresowania energią odnawialną, w obu krajach praktyczne jej wykorzystanie pozostaje poniżej możliwości.

Słowa kluczowe: odnawialne źródła energii, polityka, Polska, Japonia

Numer klasyfikacji JEL: O13, P18, Q48 